\title{
Jole
}

\section{Modeling Youth Leadership: An Integration of Personality Development}

\section{Theories and Ethics}

\section{Abstract}

Although youth leadership has been well described within the literature, the dearth of theoretically derived models that specifically reflect ethics and comprehensive nature of youth development still remains. The purpose of this article is to synthesize the existing youth leadership research and theories of personality development to propose a model of youth leadership. The resulting model includes 5 major interconnected components, such as cognitive, socio-emotional, motivational, behavioral, and ethical. As part of the model, ethics is suggested as a core of youth leadership and its development. The model can be used to inform planning of contextually reflective leadership education, specific curriculum and developmental interventions.

\section{Introduction}

For many years leadership scholars and practitioners have strived to define youth leadership and design models to illustrate its structure for practical use in leadership education (Whitehead, 2009). Existing research on youth leadership focuses on its various aspects relating to motivation to be leaders, perceptions of leadership, and leadership experiences (Hendricks, 2011; TerMaat-McGrath, 2010; Wright, 2008). Although these aspects of youth leadership are also interconnected to some youth personality elements, youth leadership as a construct is not reflective of youth personality as a whole. Scholarship seemingly is overpopulated with studies that explore only segregated aspects of youth leadership. In fact, the nature of youth leadership is often connected to youth experiences, knowledge, motivation, or skills, and is grounded in leadership definitions emerged as a result of research conducted with adult population (Hogan \& Kaiser, 2005). As a result, the definition of youth leadership as a construct lacks core characteristics of youth development (Dempster \& Lizzio, 2007; Wright, 2008). In addition, defined from perspectives of organizational theory, society, and power, theories of youth leadership often simplify its complexity.

The purpose of this article is to suggest a theoretically derived conceptual model of youth leadership based on a comprehensive synthesis of main youth personality development theories and ethics. In this article, the term 'youth' is used to reference a physical, cognitive, emotional, and socio-cultural stage of adolescence that generally occurs during the period of puberty and adulthood. For the purpose of this article, the period of youth or adolescence is associated with the teenage years between 15 and 
18 years old (Crandell, Crandell, \& Vander Zanden,

2012).

The first sections of this article situate the scholarship on youth leadership and overview cognitive, sociocultural (motivational), affective, behavioral, and ethical propositions on adolescent development. In achieving the purpose of this article, presented scholarship is synthesized into a working model of youth leadership. The next section describes components of the model and is followed by a discussion of the meaning this model might have for youth leadership theory and practice, leadership education, and policy.

\section{Overview of Literature on Youth Leadership Models}

The term 'youth leadership' has been greatly explored in education and includes characteristics associated with personality structures such as knowledge, attitudes, will and desire, decision making, reasoning, and critical thinking, intra-/interpersonal skills, and oral and written communication (De Simone, 2012; Jones, 1938; Kenton, 2012; Ricketts \& Rudd, 2002). Some leadership models are built upon youth experiences, cognition, and behavior (Kosutic, 2010; Kress, 2006; Ricketts \& Rudd, 2012). To be effective, youth leadership must be developed in environments "where skill development is encouraged through hands-on participation and by recognizing that youth experiences are transformed by the youth who participate in them" (Kress, 2006, pp.54-55). Youth leadership is, therefore, viewed as a sum of experiences emerging as a result of adolescent personal transformation and decision-making.

Another group of youth leadership studies and models centers around interpersonal and reflective qualities and include self-awareness, self-confidence, interpersonal efficacy, skills, and motivations (Owen, 2012); inspirational motivation, intellectual stimulation, and consideration (Zacharatos, Barling, \& Kelloway, 2000); and empathy, trust, and commitment (Whitehead, 2009). Youth leadership is "complex and tugs on emotional interactions" (Whitehead, 2009, p.847) furthering leader's self-awareness, selfconfidence, ability to grow leadership in others, and integration with community interests and needs.

The potential to be a leader in adulthood has also been examined in correlation to youth's social skills, extraversion, and motivation (Gottfried et al., 2011; Guerin et al., 2011). The process and extent of leadership development in adolescents is associated with individual differences in temperament and subsequent personality traits. Furthermore, youth leaders tend to have a high academic intrinsic motivation (Gottfried et al., 2011) and practice collective action, modeling, and mentoring to make a positive change (Mortensen et al., 2014). Youth reported leadership within the context of "an inclusive opportunity available to anyone who is motivated to make change happen... working for the common good, putting others' needs before one's own" (Mortensen et al., 2014, pp.457-458).

Whilst the list of youth leadership models is not limited to the aforementioned, these represent the breadth, diversity, and complexity of youth leadership development. Described theoretical propositions center primarily on youth sociocultural qualities and personality, and, depending on the research context, components of youth leadership vary. As a result, youth leadership remains a complex and ambiguous construct, and leadership definitions continue to be inconsistent. Therefore, there is a need for a more integrative approach to "develop a distinct youthdriven framework of leadership" (Mortensen et al., 2014, p.459). A comprehensive understanding of leadership reflective of youth's personality and its developmental needs can unify educational efforts to grow ethical, motivated, responsible, communityoriented and successful leaders now and in the future. 


\section{Overview of Literature on Personality Development Theories and Ethics}

Development of youth and their leadership is a complex and dynamic process. Facilitation of this process requires recognition of developmental characteristics authentic to youth (Owen, 2012). Acknowledgement of youth developmental differences and attributes helps educators decide "what to include or exclude from leadership development, communicate values and beliefs about the nature and purpose of leadership, and articulate and assess the efficacy of a leadership program's design and delivery" (Owen, 2012, p.17).

Age differences associated with the period of adolescence are particularly important in leadership development because they inform the ways youth accumulate and further their knowledge; accrue, refine and apply their skills in daily learning and socialization; and experience new educational and social situations and relationships. The process of development requires youth to adapt, design, complexify, and diversify their ways of learning and interacting with the world (Crandell, Crandell, \&
Vander Zanden, 2012). This complex process involves continuous change in cognitive, motivational, affective, behavioral, and ethical structures and is an essential part of youth growth as self-motivated, intelligent, self-aware, responsible, and adaptive individuals. The following personality categories were used to guide a comprehensive analysis of the main personality development concepts: perceptions and knowledge (Best, 1995; Crain, 1980; Crandell, Crandell, \& Vander Zanden, 2012; Evans, Lepore, Shejwal, \& Palsane, 1998; Steinberg, 2008), needs and motives (Flavell, 1985), emotions and attitudes (Bussey \& Bandura, 1999; Cloninger, 1996; Frijda, 1986; Larson \& Pleck, 1999), behaviors and actions (Bandura, 1999; Bussey \& Bandura, 1999; Chickering, 1969; Crain, 1980), and ethics (Boyd, 1988; Day, Fleenor, Atwater, Sturm, \& McKee, 2014; Freud, 1962; Kohlberg, 1973, 1975; Kohlberg \& DeVries, 1980; Kohlberg \& Hersh, 1977; Skinner, 1938). These categories were grouped into themes, such as cognitive, motivational, affective, behavioral, and ethical. Table 1 below provides a summary of theories used to inform adolescent development occurring in cognitive, motivational, affective, behavioral, and ethical personality structures.

Table 1.

Theories of Personality Development.

\begin{tabular}{|c|c|c|}
\hline Theory of & Component(-s) & Description \\
\hline Cognitive & Perception and knowledge & $\begin{array}{l}\text { Information is assimilated, stored, and organized into coherent } \\
\text { thoughts and ideas. }\end{array}$ \\
\hline Motivational & $\begin{array}{l}\text { Extrinsic and intrinsic } \\
\text { motives }\end{array}$ & $\begin{array}{l}\text { Cognition and development are activated by internal and external } \\
\text { stimuli, such as curiosity, interest, appraisal, recognition, and emotional } \\
\text { fulfillment. }\end{array}$ \\
\hline Affective & Emotions and attitudes & $\begin{array}{l}\text { Emotions are biological and social reactions stimulating the } \\
\text { development of identity-linked concepts, behavioral and judgmental } \\
\text { standards, and self-regulatory influences. }\end{array}$ \\
\hline Behavioral & Actions & $\begin{array}{l}\text { Actions are developmental outcomes of educational activities, social } \\
\text { interactions, learning, and personal change. They help youth translate } \\
\text { values, principles, and knowledge learned through social interactions } \\
\text { and self-reflection into unique experiences. }\end{array}$ \\
\hline Ethical & $\begin{array}{l}\text { Moral reasoning / Moral } \\
\text { judgment }\end{array}$ & $\begin{array}{l}\text { Judgment or choice rooted in cognitive reasoning allows for defining } \\
\text { moral (ethical) values and principles, applying them to life situations, } \\
\text { and conceptualizing such values, principles, and learned life examples } \\
\text { as abstract and universal. }\end{array}$ \\
\hline
\end{tabular}


Cognitive development. Youth personality and its structures evolve gradually. Cognitive development is a constant interaction with the environment to comprehend and create new thinking structures to expand one's perception. These structures allow one to better understand the environment by applying and testing newly developed cognitive mechanisms.

Specifically, adolescents comparing to younger children begin to think about far-reaching problems related to equity, education, social justice, and leadership. They are capable of relating such issues to their own knowledge and foresee outcomes of their actions initiated to resolve those issues. They easily grasp abstract principles and construct their own meaning relevant to their environment and previous experiences. Through active learning and purposeful engagement in learning activities, adolescents are able to better process, assimilate, and organize information simultaneously through application to specific learning activities. Youth, thus, are able to build new understanding independently from external assistance, although learning is nourished, stimulated, and challenged by the learning environment (Crandell, Crandell, \& Vander Zanden, 2012).

The changing learning environment inevitably creates situations of internal conflict. The nature of the internal conflict is described by limitations in existing cognitive processes on one hand, and the necessity of development of new ways of knowledge acquisition on the other (Steinberg, 2008). Due to lack of more sophisticated cognitive structures, new knowledge and experiences may confuse adolescents and at the same time motivate their cognition to acquire new patterns of information assimilation and retention (Evans, Lepore, Shejwal, \& Palsane, 1998). As a result, under the influence on the internal conflict, cognitive processes constantly increasingly change, adapt, and become more complex and diverse (Owen, 2012).

In addition to new understanding of the environment, youth continuously broaden their perception of the world around and relationships within it. As a result of this personalized, analyzed, and organized information (Best, 1995), perception is presented in the forms of beliefs and judgments. Enriched by and interpreted through the lenses of personal experiences, one's perception is a position that continuously evolves and develops in accordance to available developmental resources, practices, and ideas of other people. Respectively, it allows for recognizing knowledge in social and educational environments and discovering the relationships between the knowledge and experiences, and its applicability to and usefulness in various learning and social situations.

Motivational Development. Flavell (1985) suggests that human learning and development is driven by extrinsic and intrinsic stimuli. He suggests that learning that is based on personal interest and curiosity is more effective and impactful. The cognition, activated by unexpected, unfamiliar, or intriguing stimuli, centers on learning about the world rather than receiving recognition, appraisal, or some sort of external reinforcement. Intrinsic motivation "activates or intensifies human cognitive processing" (Flavell, 1985, pp.15-16) and, thus, is important for overall adolescent development. Specifically, the desire and willingness "to master problematic situations, to be effective with respect to one's environment, to be competent" (p. 19) assure continuous exploration and determine the extent of behavioral change. Intrinsic motivational factors greatly contribute to the expansion of adolescent skill mastery, their competence and effectiveness in a specific activity or discipline.

The concept of intrinsic motivation includes adolescent interest, internal rewarding, and cognitive and emotional fulfillment (Flavell, 1985). It is also viewed as adolescent engagement in consciously selected cognitive and social activities for the purposes of emotional and intellectual satisfaction. Motivated intrinsically, youth can intentionally select and explore complex issues expanding their knowledge and experiences without external instruction (Crandell, Crandell, \& Vander Zanden, 2012). 
Affective Development. In addition to youth intrinsic motivation to explore the world, their ability to be leaders now and in the future is greatly influenced by their emotions. Emotions "operate as interacting determinants" and, as a result, influence one's development bi-directionally (Bussey \& Bandura, 1999). They stimulate the development of identity-linked concepts, behavioral and judgmental standards, and self-regulatory influences (Bussey \& Bandura, 1999). Adolescents learn to recognize, appropriately express, and manage their emotions. The difference between positive and negative emotions becomes more evident and apparent, thus, enabling youth to acknowledge the impact of emotions on personal and other people's wellbeing.

Specifically, emotions can be described as biological and social reactions to events, people, other people's actions, and situations (Cloninger, 1996). Frijda (1986) defines emotions as "noninstrumental behaviors and noninstrumental features of behavior, psychological changes, and evaluative, subject-related experiences, as evoked by external or mental events, and primarily by the significance of such events" (p.4). Furthermore, they drive adolescent attention and action, help set priorities, provide personally valued goals, and excite youth interest toward self-development (Larson \& Pleck, 1999). On the other hand, when emotions are shaped by social and cultural rules, meaning how emotions should be defined and expressed by one within specific social and cultural circumstances, they can be reflective of one's values and societal norms as much as signifying of the order of community observed in one's beliefs, emotional reactions, and emotional relationships with others (Larson \& Pleck, 1999).

Behavioral Development. Adolescent ability to be active learners and members of the society is observed through their actions and behaviors. Actions and behaviors are the sum of developmental outcomes of educational activities, social interactions, learning, and personal change. They help youth translate values, principles, and knowledge learned through social interactions and self-reflection into unique experiences. Integrated with realization of interconnectedness with others, actions transform personal and social responsibilities into more complex commitments and purposes (Chickering, 1969).

Adolescent behaviors and actions evolve and become more complex and intentional under external social and educational forces (Bandura, 1999). Diversity and complexity of social situations positively correlate with the speed and quality of learning. This occurs because youth, as active social agents, continuously encounter, observe, imitate, and refine outcomes of social actions of their own and their family and community members (Crain, 1980). Those actions are embedded in youth social networks, which if encountered on a daily basis, stimulate youth active involvement with their family and community. Mostly through those networks youth learn socially important values, principles, and accepted norms of behavior that will be exercised in different learning environments in the future.

When exposed to various social and educational situations, youth have to decide how to construct their behavior. On one hand, constructing a new line of action helps evoke and revisit previous experiences, knowledge, and skills. On the other hand, the choice of what actions to take requires interplay of youth's cognition, motives and needs, emotions, and ethical values. It 'forces' adolescents to recognize the gaps in their previous knowledge and experiences, empowers them to take risks, and evaluate the consequences of their potential actions. This process is often intentional and promotes youth self-development and self-realization by triggering the needs in learning, change, and improvement (Bussey \& Bandura, 1999).

Ethical Development. Transformation of adolescent understanding, motivation, emotions, and behaviors is accompanied by the development of ethical reasoning, character, and values (Aristotle, 1985/2003; Ciulla, 2003; Klau, 2006; Kohlberg \& Hersh, 1977; Piaget, 1948). Ethical reasoning, or judgment, refers to individual's knowledge of ethics and motivation. It is primarily affected by the ability 
to empathize and the capacity for guilt (Kohlberg \& Hersh, 1977). Whether an individual experiences empathy or guilt, in an ethically challenging situation they make a choice of actions. Ethical judgment also indicates a) what individual considers as morally valuable in making a morally difficult choice and b) why they find it valuable to justify his/her choice of morally appropriate behavioral scenarios.

Character or personality is inseparable from (1) virtues that "allow [individuals] to exert rational control over their desires" and (2) values (Ciulla, 2003, p.55). Character virtues are defined as feelings and actions (Aristotle, 1985/2003; Buddha, 1967/2003; Plato, 1955) as well as positive traits (Bass \& Steidlmeier, 1999; Carr \& Steutel, 1999; Johnson, 2009; Resick et al., 2011; Rhode, 2006). Ethical values, on the contrary, are the center of moral reasoning and crucial in ethical decision-making (Rhode, 2006). They resonate to individual emotional and rational structures helping "protect one from acting badly at moments when one's sympathies happen to be in abeyance" (Bennett, 1974/2003).

Greatly impacted by Dewey's ideas on cognitive development (Dewey, 1964), current ethical development theory implies that every child is gifted with the psychological and socio-emotional capacity to progress to higher levels of moral reasoning and ethical development. During adolescence, youth learn to define ethical values and principles, apply them to life situations, and conceptualize such values, principles, and learned life examples as abstract and universal (Crain, 1980). During this process, social environment, including peers, constantly challenges youth's ethical assumptions. Critical lenses of the adolescent social community on ethical values, principles and norms of behavior stimulate youth ethical development externally and internally. On one hand, the environment creates social and educational situations that challenge youth ethical principles and values. External social forces reflected in social and educational situations present various opportunities for adolescents to learn and absorb socially acceptable rules, principles, values, and norms. Various social systems including but not limited to family, community, peer groups, school, etc. shape youth perception on their role and place in the community they reside in, broaden their understanding of implicit connections between youth actions and other people's welfare, teach legal consequences of socially destructive behavior, provide satisfaction from conducting ethical actions, and, as a result, increase their ethical conscience (Kohlberg, 1966). On the other hand, adolescents themselves consciously question, reason, and evaluate their own ethical values and behavior.

\section{Modeling Youth Leadership}

The extent to which youth can integrate their leadership with other abilities and skills helps explain how thoroughly youth develop their leadership (Owen, 2012). Based on the literature review described in previous sections, a working model of youth leadership has been developed (Figure 1). The model synthesizes earlier-described main concepts of personality development and youth leadership. The model reflects main components of youth personality and components authentic to adolescent leadership. The model expands upon the five primary domains: cognitive, motivational, affective, behavioral, and ethical, which interconnects the prior four. Youth leadership is viewed as a complex and dynamic system that integrates leadership knowledge, motivation, attitudes toward leadership development and practice, and ethical leadership actions. Specifically, youth leadership includes (a) internalized information on leadership and ethical leadership, (b) youth's positive predispositions towards leadership, its development, and positive community change; (c) willingness and readiness to further leadership potential to serve others; and (d) purposeful, mindful, responsible, and committed engagement in ethical leadership practice and decision-making. 


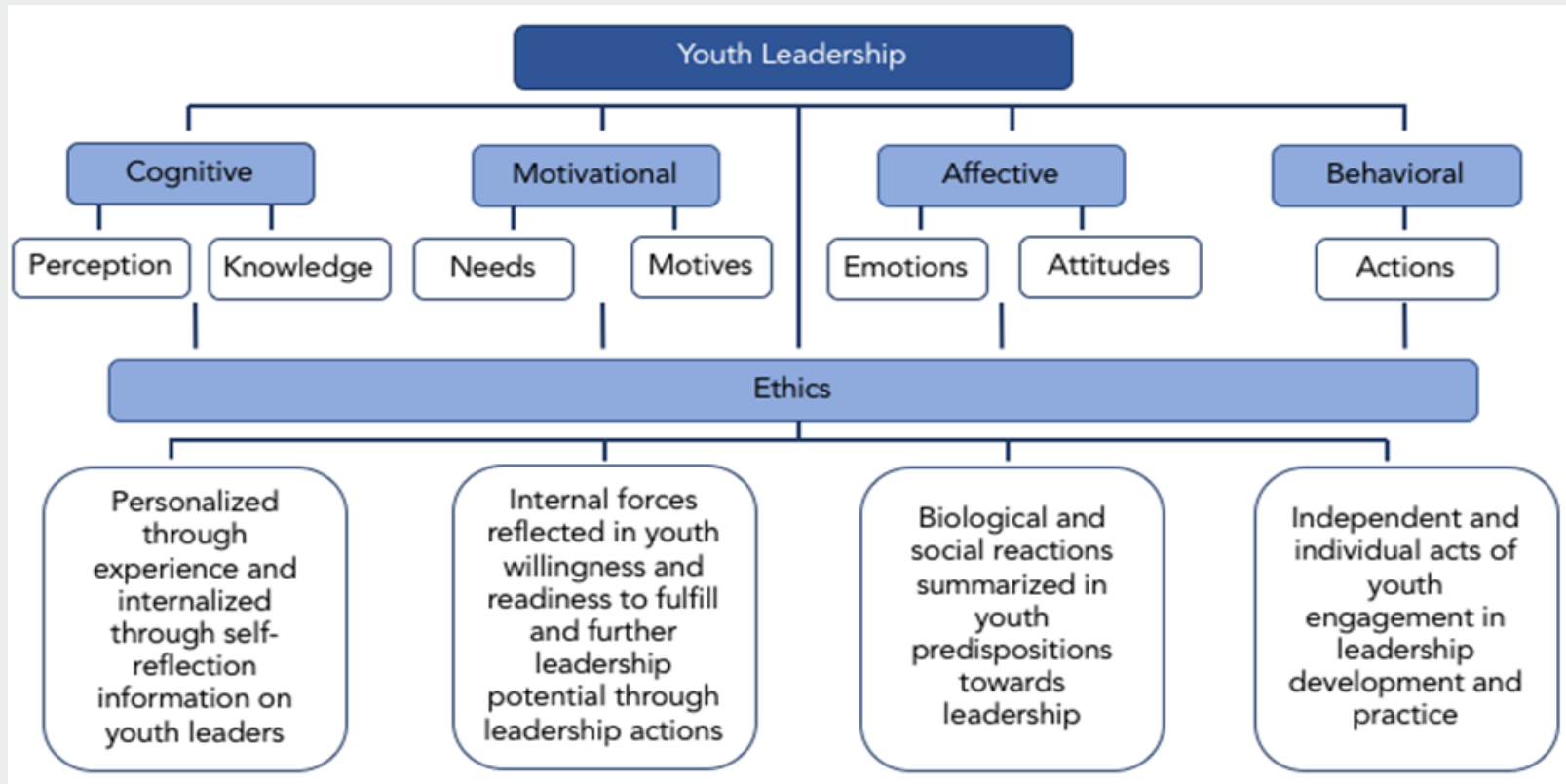

Figure 1. Modeling Youth Leadership

Cognitive domain (youth knowledge and perception of leadership). Youth leaders have an abundant and diverse knowledge of leadership; they perceive themselves and others as (potential) leaders and are able to explicitly articulate and exemplify major characteristics of youth leadership (Ricketts \& Rudd, 2002; Van Linden \& Fertman, 1998). Youth knowledge of leadership also includes understanding of connections between leadership and personality, learning, community service, and leadership role in personal development and self-actualization. Youth can define leadership in various ways and outline numerous leadership characteristics and functions. They are knowledgeable of leadership impact on personal, professional and community development. Their awareness of leadership also includes thorough understanding of ethical foundations of leadership, specifically leadership values, ethical decisionmaking, the role of responsibility in individual and group activities and projects, respect for choices of other people, importance of determination in learning, dedication to personal and group social values, etc.

Youth beliefs on the nature of leadership are summarized in youth perception of leadership (Best, 1995). Enriched by and interpreted through the lenses of personal experiences, youth perception of leadership continuously evolves and develops in accordance to available youth leadership development resources, practices, and ideas of other people. Diversity of youth knowledge of and experiences in leadership results in a wide range of existing youth insights on leadership as a construct. Through active exploration of available information and reflection on leadership, youth are able to recognize leadership in various social and educational settings, as well as differentiate its impact on the behavior of others, its role in personal and social development, and its usefulness for making a positive change at home, school, and community. 
Motivational domain (youth motivation in leadership development and practice). Leaders strive for personal growth and change (Gardner, 1990). As youth continue to further their leadership potential and meet their needs in leadership development, they begin to define their short- and long-term goals that can be accomplished only through their own efforts (Gardner, 1990). Motivation to be a leader is, therefore, crucial for youth identity and their leadership as it allows for satisfaction of needs in growing as individuals and leaders, as well as active engagement in the goal realization process.

Recall, the term 'motivation' attributes to "the energy or drive that impels a person to make choices" and "seek satisfaction of unmet needs" (Cloninger, 1996, pp.230-231). Owens (2004) argues motivation is internal "ongoing human proclivity to continue growing, developing and maturing, and being enriched by new experiences" (p.369). As a result of leadership development, adolescents become motivate to realize their capacity to fulfill leadership potential and develop their leader identity. Fostered in group settings, youth are continuously empowered to broaden their understanding of leadership, their identity as leaders, and leadership of others. They also develop appreciation of leadership development and practice, as they can see the positive impact of leadership on their group morale and relationships with group members.

Motivation also guides youth readiness to fulfill their self-actualization needs and take specific actions (Crandell, Crandell, \& Vander Zanden, 2012). There are several factors that drive the motivation of being a leader: (a) internalized and personally meaningful knowledge of youth leadership; (b) positive experiences in youth leadership development and practice; and (c) positive emotions such as satisfaction, joy, and inspiration stemming from previous leadership experiences (Chan \& Drasgow, 2001; Zachratos, Barling, \& Kelloway, 2002). When intrinsically motivated through positive experiences and inspirations, youth leaders become more aware of personal and group vision and goals, as well as the expectations of achievement from personal and group perspectives. Inspired and motivated youth can become actively involved in leadership practice and exhibit characteristics of creative thinking, selfcontrol, and self-direction (Hammond-Diedrich \& Walsh, 2006). Intrinsically interested in leadership development, youth are enabled to continuously devote their time to leadership inquiry, purposefully select leadership activities, and learn how to prioritize.

Affective domain (youth emotions and attitudes toward leadership). Actions of youth leaders are often determined by emotions and attitudes toward leadership and its practice (Cloninger, 1996; Ricketts \& Rudd, 2002; Van Linden \& Fertman, 1998). Emotions and attitudes are the core of leader personality; they direct leader behavior and serve as an expression of positive and negative leadership experiences (Mascolo \& Fischer, 2010). They also reflect youth dispositions "toward identifying themselves as leaders" (Van Linden \& Fertman, 1998, p.41). They originate in selfassessment and self-reflection, when youth have to determine the role attitudes and emotions play in the effectiveness of themselves as leaders, overall learning and community service. By reflecting on how youth felt when practicing leadership, they can make a judgment whether leadership experiences are positive or negative, whether they affect their personality or lives of other people, or whether they should continue on a leadership track or dedicate themselves to other learning activities.

One of the factors influencing youth's leadership emotions and attitudes is interactions with other people occurring as a result of youth involvement in leadership activities. Meeting new people and fostering previously established relationships allows youth to learn about the value of leadership for others, gradually expand the understanding of themselves as leaders and increase competence in leadership practice. Furthermore, relationships with peers and adults that emerged as a result of leadership bolster youth enthusiasm toward leadership development in various social and educational settings now and in the future. 
Behavioral domain (leadership actions). Youth leaders are highly participatory in school, family and community events. They recognize the importance of ethical leadership behavior and demonstrate their commitment to community and personal values through their actions (Whitehead, 2009). Leadership actions, contrary to other domains of youth leadership, are external to youth personality and are both indicators and a source of influence generated through leader's behavior (Chambers \& Phelps, 1993). Specifically, as indicators, leadership actions demonstrate youth knowledge and perception of leadership, youth motivation in leadership development and practice along with their emotions and attitudes towards leadership. Youth actions indicate the extent of leadership development, as well as the breadth and depth of interconnections between youth cognitive, motivational, and affective leadership constructs.

As a source of influence, leadership actions continuously contribute to the development of youth awareness and perception of leadership, fulfill youth needs in leadership practice, and further youth's commitment and dedication to leadership, personal and community values through using their decision-making, choice and freedom for something larger than themselves. Engaged in activities that benefit others and bring joy and a positive change to other people's lives, behavior of youth leaders is, thus, positively reinforced and encouraged. When youth practice leadership to meet the needs of others, they can experience a deep satisfaction shaping their current and future leadership behavior.

Ethics. Why is ethics important in youth leadership and what implications does it have for leadership practice? As noted by Ciulla (2003) and Klau (2006), leaders "often have more and greater obligations and responsibilities" (Ciulla, 2003, p.1), however, without ethical virtues, values, decision making, and ethical behavior, leadership can be destroying to oneself and people around (Ludwig \& Longenecker, 1993/2003).
Leader's character or virtues play a crucial role in leadership (Johnson, 2009) and greatly correspond to the inner world of a leader. For instance, Aristotle (1985/2003) wrote that "we are by nature acquire [virtues], and reach out complete perfection through habit" (p.56). Only through continuous and mindful self-refinement and self-reflection an individual can acquire ethical leadership virtues such as bravery, generosity, honor, honesty, and friendliness. Based on Aristotle's propositions, Carr and Steutel (1999) also include kindness, patience, endurance, courage, and thoughtfulness. Integrity, humility, reverence, optimism, compassion, and justice foster leader's character as well (Johnson, 2009). A recent crosscultural study on the meaning of ethical leadership (Resick et al., 2011) supports and broadens the list of leader's virtues to trustworthiness, sincerity, selfdiscipline, authenticity, and ethical awareness.

Leader's values are also central to ethical leadership. Among these values scholars identify creativity, enthusiasm, love for people, connectedness, and life purpose (Shah lqbal, 2009). The leadership values also include reciprocity, trust, acceptance to create an organization and the world around with a heart and soul, and welfare of others (Caldwell \& Dixon, 2010); collaboration and mutual responsibility (Msila, 2012) along with accountability, dignity, respect, effective communication, empathy, and tolerance (Resick et al., 2011).

As stated earlier in this paper, ethical behavior of a youth leader is informed by their leadership values, character, and social, cultural, and economic circumstances (Knights \& O'Leary, 2006). According to Resick and his team (2011), acting as an ethical leader involves complying with laws, regulations, and professional [educational/learning] guidelines, taking personal responsibility, demonstrating understanding and being helpful, making fair and just decisions, putting interests of others ahead of personal, and fosterin sustainability of trusty relationships and positive impact on community. 


\section{Conclusion}

The importance of youth leadership and the value associated with its development are well explored from both theoretical and practical perspectives. Generally, leadership models have presumed a position of power and authority to accompany leadership traits; however, the context of adultbased leadership research is not applicable to youth leadership (Owen, 2012; Stein et al., 2005). Previous scholarship has proposed various elements of youth leadership development and practice (Chan, 2000; Whitehead, 2009); nevertheless, the existing models lacked age-appropriate, changing pro-social, ethical nature to adequately meet adolescent needs in personal and leadership growth (Owen, 2012; Whitehead, 2009).

The purpose of this article was to develop a working, theoretically grounded conceptual model of youth leadership. The proposed model synthesized and integrated the previously researched characteristics of youth leadership and main personality development theories. The model resulted in identification of five major youth leadership domains: cognitive, motivational, affective, behavioral, and ethical. The conceptual model grounded in ethics and specific characteristics of youth personality development offers important benefits to adolescent leadership, personal development, and leadership education as it represents an action toward self-realization, selfimprovement, and community change.

The potential to influence youth leadership presented in the working model may hold a promise for dramatic improvement in youth leadership education. When organizing youth leadership education, this model can be used to personalize leadership development and other cognitive learning activities, inform community and service learning, and empower youth to become better leaders, community change agents, and responsible decision makers. The working model of youth leadership proposed in this article can help educators and leadership practitioners encourage the learning and practice of ethical leadership and values, such as responsibility, commitment, and personal integrity.

Further, when designing youth leadership development activities, educators should consider adolescent cognitive readiness for learning leadership as a construct. Youth at any level of cognitive development should be offered personalized feedback and activities encouraging their interest in learning and practicing leadership simultaneously (Day, Fleenor, Atwater, Sturm, \& McKee, 2009; Owen, 2012). In addition, purposeful and meaningful organization of youth engagement in community and service learning can enrich their knowledge of leadership and broaden their perception of leadership through numerous leadership examples existing in the community. Collaboration with school faculty and educators can also encourage youth understanding of the importance of being a leader and the role leadership can play in learning and personal development. School administration and staff can become leadership role models for youth and exemplify leadership through their own actions.

Since adolescents learn greatly in diverse environments, to foster youth positive attitudes towards leadership and its development, leadership educators can imbue the theory of leadership with practical situations. Such situations can be created during service learning, in the classroom, and at any extracurricular event. Although created situations can help integrate youth leadership knowledge, skills, and behaviors, educators should pay a careful attention to youth's individual differences. It is crucial to engage youth in encouraging and inspirational activities. Collaboration with youth on community- and service-oriented projects, use of video materials that portray a positive personal and/or social change as a result of leader's actions, and purposeful design of school activities capable of generating positive leadership experiences and inspiring adolescents to be the better self, citizens, and leaders are some of the practices that can be offered to youth to foster their leadership 
development.

To encourage the practice of ethical behavior of youth leaders, leadership education can and should be centered on activities that contribute to the development of youth virtues and ethical values. For instance, service learning and continuous self-reflection shift youth attitudes from self-centered to more community-oriented. Additionally, ethics-based leadership can empower adolescents to be more engaged and committed to community service, as well as foster adolescent personal development and decision-making (Terry, 2003; Webster \& Worrell, 2008). Supervised and purposefully-organized service learning instruction can nurture youth responsibility for consequences of their actions, for broadening their experiences, knowledge, and skills, and for creating opportunities for community contribution (Kielsmeier, Scales, Roehlkepartain, \& Neal, 2004). Youth leadership educators should consider youth developing moral reasoning while teaching ethics of leadership. It is imperative for instructors to humanize and personalize ethical values and principles, as well as develop integrity and congruence between adolescent personal actions and articulated values (Burns, 1978).

Additionally, to bring into practice real leadership experience and acknowledge the needs of youth learners, a recommended next step would be to focus on examination and operationalization of various levels of youth leadership development based on the proposed leadership domains. The levels should be researched in accordance to individual levels of personal and ethical development of youth and incorporate the ideas of knowledge and skill acquisition in adolescence. The model should further be aligned with valid assessment instruments to establish the baseline for the assessment of leadership potential.

Future research-based models of youth leadership linked to specific educational and social contexts are also suggested. Additional research may reveal supplemental characteristics of youth leadership and generate models that are more context sensitive and responsive to various learning environments and youth populations. Leadership education should be contextually appropriate; diverse and extensive youth leadership models should inform educational decisions and efforts when fostering youth drive toward better leadership, personal and collective accomplishment, improved quality of life, and social progress. 


\section{References}

Aristotle (1985). Virtue of ethics. In J.B. Ciulla (2003) (Ed.). The ethics of leadership. Belmont, CA: Wadsworth, Cengage Learning. pp. 55-63.

Bandura, A. (1999). Social cognitive theory of personality. In Pervin, L. \& John, O. (Eds.), Handbook of Personality. 2nd ed., 154-196. New York, NY: Guilford Press.

Bass, B. M., \& Steidlmeier, P. (1999). Ethics, character, and authentic transformational leadership behavior. Leadership Quarterly, 10(2), 181-217.

Bennett, J. (1974). The conscience of Huckleberry Finn. In J.B. Ciulla (2003) (Ed.). The ethics of leadership. Belmont, CA: Wadsworth, Cengage Learning. pp. 81-91.

Best, J.B. (1995). Cognitive psychology (4th ed.). St. Paul, MN: West Publishing Company.

Boyd, D. (1988). Introduction: Lawrence Kohlberg as a mentor. Journal of Moral Education, 17(3), 167-171.

Buddha (1967). The first sermon and the synopsis of truth. In J.B. Ciulla (2003) (Ed.). The ethics of leadership. Belmont, CA: Wadsworth, Cengage Learning. pp. 64-68.

Burns, J.M. (1978). Leadership. New York, NY: Harper \& Row.

Bussey, K., \& Bandura, A. (1999). Social cognitive theory of gender development and differentiation. Psychological Review, 106(4), 676-713.

Caldwell, C., \& Dixon, R. D. (2010). Love, forgiveness, and trust: Critical values of the modern leader. Journal of Business Ethics, 93, 91-101. DOI: 10.1007/s10551-009-0184-z

Carr, D., \& Steutel, J. (1999). Virtue ethics and moral education. New York, NY: Routledge.

Chambers, T., \& Phelps, C.E. (1993). Student activism as a form of leadership and student development. NASPA Journal, 31(1), 19-29.

Chan, D.W. (2000). Assessing Leader ship among Chinese Secondary Students in Hong Kong: The Use of the Roets Rating. Gifted Child Quarterly, 44(2), 115-122.

Chan, K.-Y., \& Drasgow, F. (2001). Toward a theory of individual differences and leadership: Understanding the motivation to lead. Journal of Applied Psychology, 86(3), 481-498.

Chickering, A.W. (1969). Education and identity. San Francisco, CA: Jossey-Bass.

Ciulla. J.B. (2003). The ethics of leadership. Belmont, CA: Wadsworth, Cengage Learning.

Cloninger, S.C. (1996). Personality: Description, dynamics, and development. New York, NY: Freeman.

Crain, W.C. (1980). Piaget's Cognitive-Developmental Theory. In Theories of Development: Concepts and Applications. Englewood Cliffs, NJ: Prentice-Hall.

Crandell, T.L., Crandell, C.H. \& Vander Zanden, J.W. (2012). Human development (10th ed.). New York, NY: McGraw-Hill. 
Day, D.V., Fleenor, J.W., Atwater, L.E., Sturm, R.E., \& McKee, R.A. (2014). Advances in leader and leadership development: A review of 25 years of research and theory. The Leadership Quarterly, 25, 63-82.

Dempster, N., \& Lizzio, A. (2007). Student leadership: Necessary research. Australian Journal of Education, 51(3), 276-285.

De Simone, L. (2012). Youth leadership development from the grade 8 perspective: A case study of a schoolbased program (Master's thesis). Retrieved from ProQuest Dissertations \& Theses.

Dewey, J. (1964). What psychology can do for the teacher. In R. Archambault, Ed., John Dewey on Education: Selected Writings. New York, NY: Random House.

Evans, G.W., Lepore, S.J., Shejwal, B.R., \& Palsane, M.N. (1998). Chronic residential crowding and children's well-being: An ecological perspective. Child Development, 69, 1514-1523.

Flavell, J.H. (1985). Cognitive development (2nd ed.). Englewood Cliffs, NJ: Prentice-Hall.

Freud, S. (1962). Civilization and its discontents. New York, NY: W.W. Norton.

Frijda, N.H. (1986). The emotions. (Studies in emotions and social interactions). New York, NY: Cambridge University Press.

Gardner, J.W. (1990). On leadership. New York, NY: The Free Press.

Gottfried, A.E., Gottfried, A.W., Reichard, R.J., Guerin, D.W., Oliver, P.H., \& Riggio, R.E. (2011). Motivational roots of leadership: A longitudinal study from childhood through adulthood. The Leadership Quarterly, 22, 510-519.

Guerin, D.W., Oliver, P.H., Gottfried, A.W., Gottfried, A.E., Reichard, R.J., \& Riggio, R.E. (2011). Childhood and adolescent antecedents of social skills and leadership potential in adulthood: Temperamental approach/ withdrawal and extraversion. The Leadership Quarterly, 22, 482-494. DOI: 10.1016/j.leaqua.2011.04.006

Hammond-Diedrich, K.C., \&Walsh, D. (2006). Empowering youth through a responsibility-based cross-age teacher program. An investigation into impact and possibilities. The Physical Educator, 63(3), 134-142.

Hendricks, R. (2011). Where and how do youth learn leadership? (Master's thesis). Retrieved from ProQuest Dissertations \& Theses.

Hogan, R., \& Kaiser, R.B. (2005). What we know about leadership. Review of General Psychology, 9(2), 169180. DOI: 10.1037/1089-2680.9.2.169

Johnson, C.E. (2009). Meeting the ethical challenges of leadership: Casting light or shadow (3rd Ed.). Thousand Oaks, CA: SAGE Publications.

Jones, A.J. (1938). The education of youth for leadership (1st ed.). New York and London: McGraw-Hill.

Kenton, A. (2012). Youth leadership development: A case study of an urban public high school program (Doctoral dissertation). Retrieved from ProQuest Dissertations \& Theses.

Kielsmeier, J.C., Scales, P.C., Roehlkepartain, E.C., \& Neal, M. (2004). Community service and service-learning in public schools. Reclaiming Children and Youth, 13(3), 138-143. 
Klau, M. (2006). Exploring youth leadership in theory and practice. New Directions for Youth Development, 109, 57-87. DOI: 10.1002/yd.155

Knights, D., \& O'Leary, M. (2006). Leadership, ethics and responsibility to the other. Journal of Business Ethics, 67, 125-137. DOI: 10.1007/s10551-006-9008-6

Kohlberg, L. (1966). Moral education in the schools: A developmental view. The School Review, 74(1), 1-30.

Kohlberg, L. (1973). The claim to moral adequacy of a highest stage of moral judgment. The Journal of Philosophy, 70(18), 630-646.

Kohlberg, L. (1975). The cognitive-developmental approach to moral education. The Phi Delta Kappan, $56(10), 670-677$.

Kohlberg, L., \& DeVries, R. (1980). Don't throw out the Piagetian baby with the psychometric bath: Reply to Humphreys and Parsons. Intelligence, 4, 175-177.

Kohlberg, L. \& Hersh, R.H. (1977). Moral development: A review of the theory. Theory Into Practice, 12(2), 53-59.

Kosutic, I. (2010). Constructing youth leadership (Doctoral dissertation). Retrieved from ProQuest Dissertations \& Theses.

Kress, C. (2006). Youth leadership and youth development: Connections and questions. New Directions for Youth Development, 109, 45-56. DOI: 10.1002/yd.154

Larson, R., \& Pleck, J. (1999). Hidden feelings: Emotionality in boys and men. In Bernstein, D. (Ed.), Gender and motivation, 45, 25-49. Lincoln, London: University of Nebraska Press.

Ludwig, D., \& Longenecker, C. (1993). The Bathsheba syndrome: The ethical failure of successful leaders. In J.B. Ciulla (2003) (Ed.). The ethics of leadership, 70-81, Belmont, CA: Wadsworth, Cengage Learning.

Mascolo, M.F., \& Fischer, K.W. (2010). The dynamic development of thinking, feeling and acting over the lifespan. In Overton, W.F. (Ed.), Biology, cognition and methods across the life-span. Vol. 1 of the Handbook of life-span development, 149-194, Hoboken, NJ: Wiley.

Mortensen, J., Lichty, L., Foster-Fishman, P., Harfst, S., Warsinske, K., \& Abdullah, K. (2014). Leadership through a youth lens: Understanding youth conceptualizations of leadership. Journal of Community Psychology, 42(4), 447-462. DOI: 10.1002/jcop.21620

Msila, V. (2012). Fostering an effective school through moral leadership: A South African case study. International Journal of Social Sciences and Education, 2(1), 174-192.

Owen, J. E. (2012). Using student development theories as conceptual frameworks in leadership education. New Directions for Student Services, 2012(n140), 17-35. DOI: 10.1002/ss.20029

Owens, R.G. (2004). Organizational behavior in education: Adaptive leadership and school reform. Boston, MA: Pearson.

Piaget, J. (1948). The moral judgment of the child. 2nd Ed. Glencoe, IL: Free Press. 
Plato (1955). The Republic. Baltimore, MA: Penguin Books Inc.

Resick, C.J., Martin, G.S., Keating, M.A., Dickson, M.W., Kwan, H.K., \& Peng, C. (2011). What ethical leadership means to me: Asian, American, and European perspectives. Journal of Business Ethics, 101, 435-457. DOI: 10.1007/s10551-010-0730-8

Rhode, D.L. (2006). Moral leadership: The theory and practice of power, judgment, and policy. San Francisco, CA: Jossey-Bass.

Ricketts, J.C., \& Rudd, R.D. (2002). A comprehensive leadership educational model to train, teach, and develop leadership in youth. Journal of Career and Technical Education, 19(1), 7-17.

Shah Iqbal, J. (2009). Spiritual aspects of leadership development: Moral approach towards understanding leadership phenomenon. Dialogue, 4(3), 387-408.

Skinner, B. (1938). The behavior organisms: An experimental analysis. Oxford, England: Appleton-Century.

Stein, J.A., Wood, E., Walker, J.A., Kimball, E.M., Outley, C.W., \& Michael, B. (2005). The youth development leadership experience: Transformative, reflective education for youthwork practitioners. Child and Youth Care Forum, 34(4), 303-325. DOI:10.1007/s10566-005-4096-5

Steinberg, L. (2007). Risk taking in adolescence: New perspectives from brain and behavioral science. Association for psychological science, 16(2), 55-59.

Steinberg, L. (2008). A social neuroscience perspective on adolescent risk-taking. Developmental Review, 28(1), 78-106.

TerMaat-McGrath, M.M. (2010). The urgency of youth leadership development: The impact of the Wisconsin Association of School Council's Leadership Camp on the lives of participants (Doctoral dissertation). Retrieved from ProQuest Dissertations \& Theses.

Terry, A.W. (2003). Effects of service learning on young, gifted adolescents and their community. Gifted Child Quarterly, 47(4), 295-308. DOI: 10.1177/001698620304700406

Van Linden, J.A., \& Fertman, C.I. (1998). Youth leadership: A guide to understanding leadership development in adolescents: Jossey-Bass Publishers.

Webster, N.S., \& Worrell, F.C. (2008). Academically talented students' attitudes toward service in the community. Gifted Child Quarterly, 52(2), 170-179. DOI: 10.1177/0016986208316038

Whitehead, G. (2009). Adolescent leadership development: Building a case for an authenticity framework. Educational Management Administration and Leadership, 37(6), 847-872. DOI: $10.1177 / 1741143209345441$

Wright, D. (2008). "For us, by us": Young people's leadership, participation and agency in a youth-led project for community development (Doctoral dissertation). Retrieved from ProQuest Dissertations \& Theses.

Zacharatos, A., Barling, J., \& Kelloway, K.E. (2000). Development and effects of transformational leadership in adolescents. Leadership Quarterly, 11(2), 211-226. 